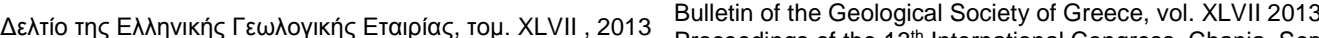
Proceedings of the $13^{\text {th }}$ International Congress, Chania, Sept.

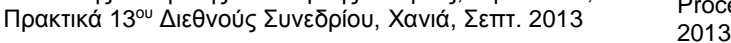

\title{
NATIONAL REPORTING CODES FOR THE MINERAL INDUSTRY: THE CASE OF JORC IN AUSTRALIA
}

\author{
Kalaitzidis S. ${ }^{1,2}$ \\ ${ }^{1}$ Integral Resource Consulting Pty Ltd, Brisbane, Australia, stavros.kalaitzidis@integralrc.com \\ ${ }^{2}$ Department of Geology, University of Patras, Rio-Patras, Greece
}

\begin{abstract}
A revised version of the Australasian Code for Reporting of Exploration Results, Mineral Resources and Ore Reserves commonly called the JORC Code was released in Australia in December 2012. This paper provides a summary of the principles that guide the Code, and the definitions therein, as well as the rationality behind adopting the Code as a Public Reporting tool. Brief examples of reporting requirements are also discussed. Additionally, references and a general comparison to the Pan-European Reserves \& Resources Reporting Code (PERC standard) are presented. Although, in Greece there is no relevant Regulatory Framework in place yet or enforcement of any International Code, the adaptation of PERC is probably ahead, and hence this paper aims to open the discussion among geoscientists and mining engineers for the opportunities and the challenges that they will face.
\end{abstract}

Key words: Mineral Resources, Ore Reserves, Competent Person, JORC, PERC.

\section{Пєрí $\eta \psi \eta$}

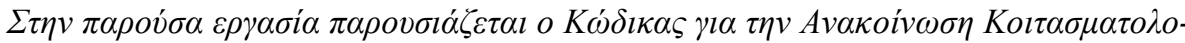

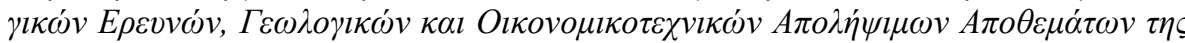

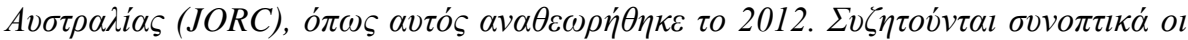

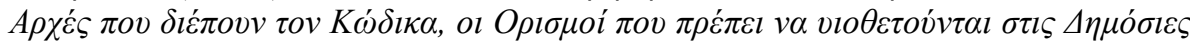

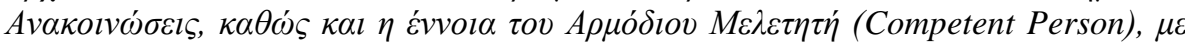

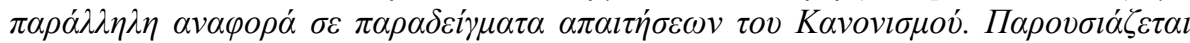

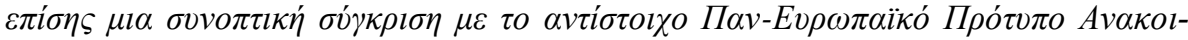

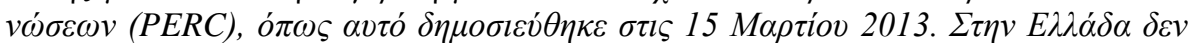

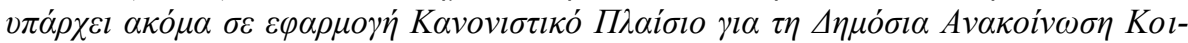

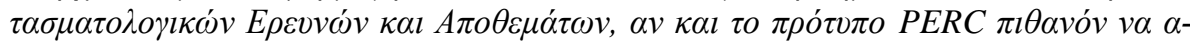

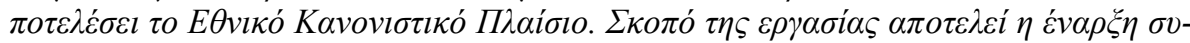

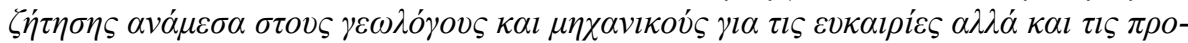

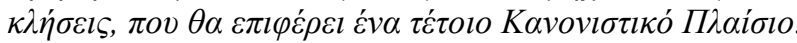

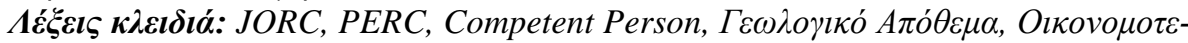

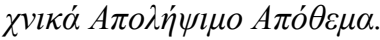

\section{Introduction}

During the last 20 years there have been significant activities at international level to standardize the reporting and the classification of mineral resources (e.g. UNFC, 2009; CIM, 2011, NI 43-101,

XLVII. No $3-1628$ 
2011; PERC, 2013). Australia was one of the leading countries in implementing standards and guidelines since 1989 with the first edition of the Joint Ore Reserves Committee Code (JORC, www.jorc.org). The Code was adopted the same year by the Australian Securities Exchange (ASX, 2013) and by the New Zealand Market (NZX) in 1992. Other jurisdictions that nowadays accept the Code include, Hong Kong, Papua New Guinea, Singapore, South Africa, UK, UAE and Europe (Goddard, 2013).

In 2012 the Joint Ore Reserves Committee released a new edition of the Code (JORC, 2012), after both national and international cooperation particularly within the framework of the Committee for Mineral Reserves International Reporting Standards (CRIRSCO, 2013), whose members are National Reporting Organizations, from Australia, Canada, Chile, Europe (PERC, 2013), Russia, South Africa, and USA.

The JORC Code has been adopted by the two main Geoscientific Professional bodies in Australia, the Australasian Institute of Mining and Metallurgy (The AusIMM, www.ausimm.com.au) and the Australian Institute of Geoscientists (AIG, www.aig.org.au) and it is binding for their members. The Code sets out minimum standards, recommendations and guidelines for Public Reporting purposes by the listed companies in Stock Markets, who must comply with these standards. It is a Principles based Code for Reporting and does not regulate the means and the methods, which the Competent Persons may use to estimate the Mineral Resources or Ore Reserves.

Greece doesn't have yet a formal framework for Reporting Purposes, neither through the professional bodies of GEOTEE and TEE or the Athens Stock Market (ATHEX). Nor is there any known open discussion on these aspects. The most recent published Pan-European Standard (PERC, 2013) however, in which the Association of Greek Geologists $(\Sigma E \Gamma)$ is a member through the European Federation of Geologists (http://www.eurogeologists.de), might provide a new dynamic for the Code to come into effect. Nevertheless, the current public discussion in Greece is lacking and the legal framework seems also to be out-of-date and needs to be amended for such a Code to be implemented. For example there is no common Professional Organization for the Mining Sector Professionals, mainly Geologists and Mining Engineers, who are the Competent Persons in most cases.

This paper provides a summary of the principles that guide the Australasian JORC Code, and the definitions therein, as well as the rationality behind adopting the Code as a Public Reporting tool. Brief examples of reporting requirements are also discussed. The aim is to open the discussion among the geoscientists and mining engineers for the opportunities and the challenges that the adoption of a Reporting Code will impose.

It should be cautioned however, that for the exact definitions and comprehensive guidelines the reader should refer to the formal JORC Code (2012) website and documentation.

\section{Background of JORC}

In Australia the necessity for regulated public announcements has its genesis in 1969 when the bubble of the Poseidon NL share prices occurred; Poseidon NL was a mining exploration company that made a major nickel discovery at Windarra in Western Australia (Simon, 2003). The share price of the company rose from $\$ 0.80$ in September 1969 to $\$ 280$ in February of 1970, based on drilling results and the high Ni price of that time. Simultaneously, other small exploration companies were announcing or better rumouring exploration results not based on real data; but due to the euphoria in the general public's perception these companies saw their shares skyrocketing, along with the All Mining Index. Finally, the All Mining Index fell rapidly in November 1971, due to lowering Ni prices, as well as due to overrating several deposits, having a significant impact on the perceived reliability of the mining sector and its ability to raise capital. The investigation that followed highlighted that "the stock market had been poorly regulated and that much of the information relied upon by investors was uncorroborated rumour".

XLVII, No $3-1629$ 
This gap was meant to be filled by the establishment of the Joint Ore Reserves Committee (JORC), which since published several Reports and Recommendations on the classification and Public Reporting of Ore Reserves, with the $1^{\text {st }}$ edition of the JORC Code in 1989 (JORC, 2012). The latest edition in 2012 aims to significantly increase the level of transparency and disclosure that is required in Public Reports to ensure investors' confidence in the mineral industry.

\section{Principles of JORC}

The JORC Code is governed by three Principles, those of Transparency, Materiality and Competence (Fig. 1):

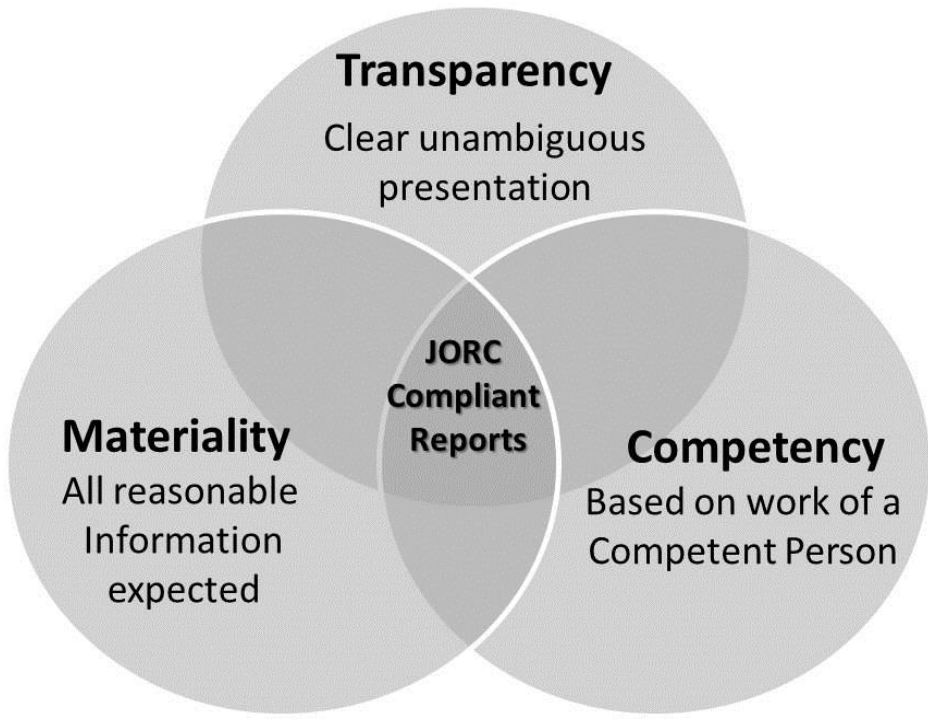

Figure 1 - Principles governing the application of JORC Code (Hunt, 2013).

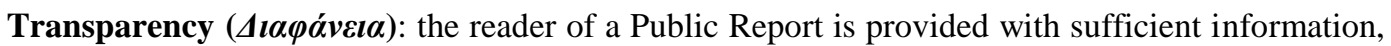
the presentation of which is clear and unambiguous, to understand the report and not be misled by this information or by omission of material information that is known to the Competent Person.

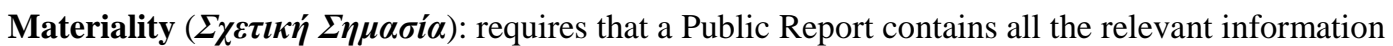
that investors and their professional advisers would reasonably require, and reasonably expect to find in the report, for the purpose of making a reasoned and balanced judgement regarding the Exploration Results, Mineral Resources or Ore Reserves being reported. Where relevant information is not supplied an explanation must be provided to justify its exclusion.

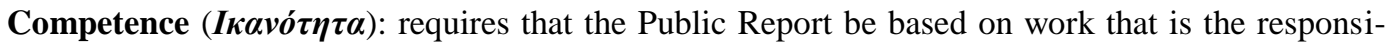
bility of suitably qualified and experienced persons who are subject to an enforceable professional code of ethics (the Competent Person).

The wording of these definitions is almost similar within the PERC 2013 Code, with minor differences in the definition of Transparency (Table 1). Additionally, the PERC Code includes additionally in the principles section the Impartiality, according to which the Competent Person's work is not unduly influenced by the Organization commissioning the Report.

\section{Competent Person}

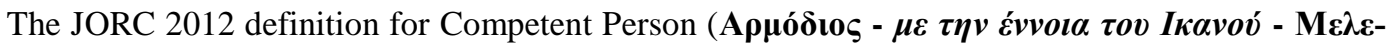

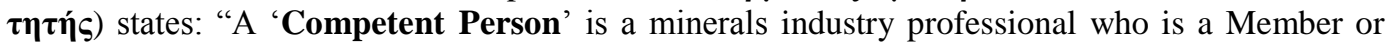
Fellow of The Australasian Institute of Mining and Metallurgy, or of the Australian Institute of 
Geoscientists, or of a 'Recognised Professional Organisation' (RPO), as included in a list available on the JORC and ASX websites. These organisations have enforceable disciplinary processes including the powers to suspend or expel a member. A Competent Person must have a minimum of five years relevant experience in the style of mineralisation or type of deposit under consideration and in the activity which that person is undertaking".

Table 1 - Comparison between JORC (2012) and PERC (2013).

\begin{tabular}{|l|l|}
\hline \multicolumn{1}{|c|}{ JORC } & \multicolumn{1}{c|}{ PERC } \\
\hline $\begin{array}{l}\text { Three Principles: Transparency, Materiality, } \\
\text { Competence }\end{array}$ & $\begin{array}{l}\text { - Four Principles: Transparency, Materi- } \\
\text { ality, Competence, Impartiality } \\
\text { Note: Similar definitions apart for } \\
\text { "Transparency", for which the part } \\
\text { "..to understand the report and not be } \\
\text { misled by this information or by omis- } \\
\text { sion of material information that is } \\
\text { known to the Competent Person" is } \\
\text { omitted. }\end{array}$ \\
\hline $\begin{array}{l}\text { Terminology: Exploration Results, Mineral Re- } \\
\text { sources, Ore Reserves }\end{array}$ & $\begin{array}{l}\text { Terminology: Exploration Results, Miner- } \\
\text { al Resources, Mineral Reserves }\end{array}$ \\
\hline $\begin{array}{l}\text { Table of Assessment and Reporting Criteria is } \\
\text { enforced to be reported on "if not, why not" } \\
\text { basis. }\end{array}$ & $\begin{array}{l}\text { "The authors of reports should both identi- } \\
\text { fyd evaluate these important factors in } \\
\text { their reports" / it is not necessary... to } \\
\text { comment on each item of Table 1" }\end{array}$ \\
\hline $\begin{array}{l}\text { Prohibited to add financial value to "in situ" } \\
\text { estimates }\end{array}$ & \multicolumn{2}{|l}{} \\
\hline
\end{tabular}

Recognised Professional Organizations (RPO) from Europe include the National Associations which constitute the European Federation of Geologists (EFG, http://www.eurogeologists.de), however not all the members of EFG are recognized. Only members entitled to the professional tittle EurGeol, belonging to member associations of the EFG are recognised as fulfilling the requirements for recognition as members of a RPO (PERC, 2013). At this stage from Greece the member of EFG is the Association of Greek Geologists (www.geologist.gr), but it seems that this membership is not recognised.

The current legislative tool in Greece for reporting of mineral resources and ore reserves, as well as for defining responsibilities between geologists and mining engineers is still the Mining Code 210/1973, with some modifications during the last 30 years. The new Act for Mining and Quarrying Activities (AMQA, 2001) intends to modernize Greek legislation regarding also the studies required to establish mining activities; however there are no provisions for reporting competencies. If Greece is going to adopt a modern reporting code, modification of the legislation might be necessary or even a re-consideration of the Professional Organizations/Chambers of the Mining Professionals, i.e. the establishment of a forum that can host both Geologists, who know are associated in GEOTEE (GeoTechnical Chamber of Greece) and Mining Engineers, who are now associated in TEE (Technical Chamber of Greece), dealing with the Resource and Mining industry.

\section{Reporting Terminology}

The JORC Code defines the terminology that must be used when reporting Exploration Results

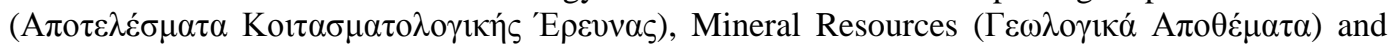

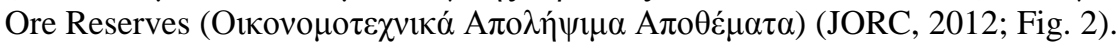

$\underline{\text { XLVII, No } 3-1631}$ 
The main objective of the definitions is to distinguish between the different levels of knowledge and confidence in the geological characteristics of the deposits, as well as in the "Modifying Factors", which drive the transition of a Mineral Resource to Ore Reserve.

Exploration Results refer to information commonly reported on early stages of exploration when the available data is not sufficient to allow for reasonable estimates of a Mineral Resource. As the exploration program proceeds and the gathered data, both structural and quality, starts satisfying the requirement for reasonable prospects for eventual economic extraction, the occurrence of the material can be defined as Mineral Resource and classified according to the three categories of

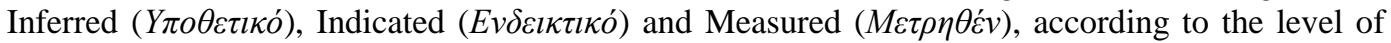
geological confidence. The intention of the Code is that geological confidence should not be a matter of qualitative stochastic approaches but rather an outcome of auditable scientifically-solid geological procedures and methods, suitably reviewed by the Competent Person using their experience in the commodity and style of mineralisation. Tools that are available to the Competent Persons include published guides for a specific commodity, e.g. the Australian Guidelines for Estimating and Reporting of Inventory Coal, Coal Resources and Coal Reserves (2003), geostatistical studies, etc, as well as a quite comprehensive checklist of Assessment and Reporting Criteria, listed within the JORC Code.

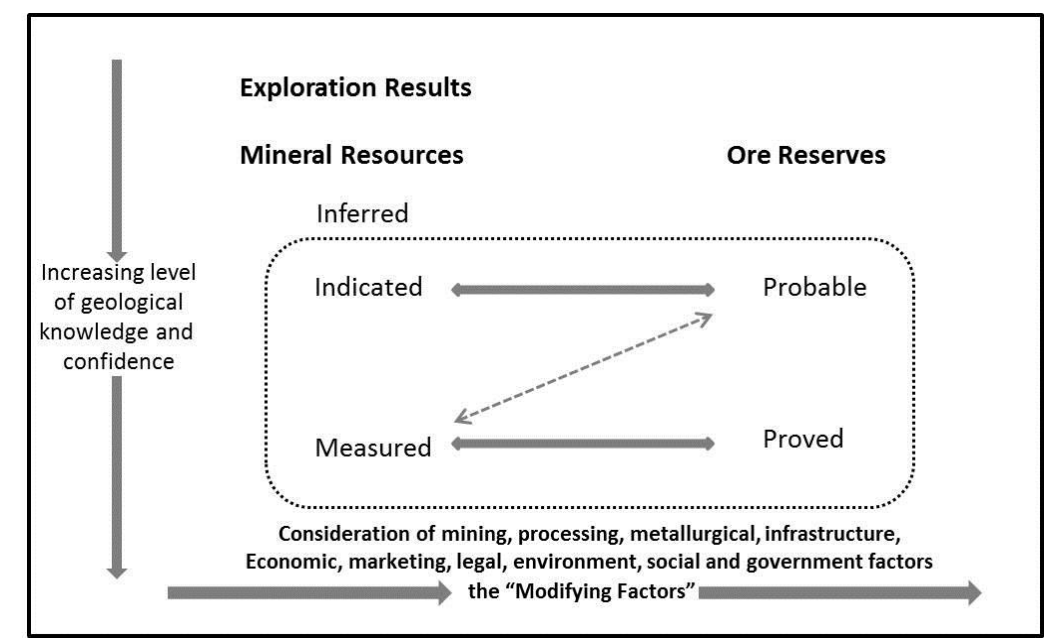

Figure 2 - General relationship between Exploration Results, Mineral Resources and Ore Reserves (according to JORC 2012).

By continuing the exploration program and most significantly by applying the "Modifying Factors" a portion of the Mineral Resource (only the Indicated or Measured) can eventually be assigned as Ore Reserve (Mineral Reserve according to the PERC 2013, Table 1), and classified as Probable $(\Pi \imath \theta \alpha v o ́)$ or Proved $(\mathrm{B} \varepsilon \beta \alpha \iota \omega \mu \varepsilon ́ v o)$. 'Modifying Factors' are considerations used to convert Mineral Resources to Ore Reserves. These include, but are not restricted to, mining, processing, metallurgical, infrastructure, economic, marketing, legal, environmental, social and governmental factors (JORC, 2012).

\section{Assessment and Reporting Criteria}

The JORC Code includes a checklist for use when preparing Public Reports. This checklist is compulsory to be reported on an "if not why not" basis for initial or materially changed estimates, which means that the Competent Person must discuss all the aspects described in the JORC Checklist, and if for some of these Sections there are no data, the reason and possible impact should be mentioned. This is in contrast to the PERC Code, according to which it is not necessary to comment on every aspect (Table 1). Sections that are prescribed under the JORC Code include:

XLVII, No $3-1632$ 
- Sampling Techniques and Data: e.g. information on drilling techniques, data spacing and distribution, logging, sub-sampling, quality assays, etc.

- Reporting of Exploration Results: e.g. information on tenements, previous exploration surveys, general geology and further work.

- Estimation and Reporting of Mineral Resources: e.g. information on database integrity, geological interpretations, estimation and modelling techniques, cut-off parameters, metallurgical and environmental factors and assumptions and classifications.

- Estimation and Reporting of Ore Reserves: e.g. information on mineral resource estimate for conversion to ore reserve, site visits of the Competent Person, cut-off parameters, mining factors or assumptions, infrastructure, costs, revenue factors, market, social and economic assessments.

It is noteworthy to mention that the Code emphasizes as best industry practise to have audits or reviews of the Mineral Resources and Ore Reserves estimates.

\section{Implementing the revised JORC Code}

The implementation of reporting systems like the JORC and PERC imposes reasonable barriers on the language that is used to describe Exploration Results, Resources and Reserves. Some examples are described below (Stoker and Berry, 2013).

Terms like "geological reserve", "exploration resources", "mining inventories" etc. are not permitted; Total Mineral Resources or Total Ore Reserves are also not permitted, unless they are also reported under their sub-classification according to Figure 2.

Certain provisions are in place so that the terms "tonnage" and "average grades" cannot be used unless specific cautionary statements are included when reporting Exploration Targets.

It is prohibited to introduce financial values to any "in situ" or "in ground" estimations, since no "Modifying Factors" are taken into consideration. Mineral Resources and Ore Reserves must not be reported in terms of "metal/mineral concentration" unless the corresponding "tonnage" and "grades" are also reported.

Additional requirements are imposed for the technical and economic studies that are required, e.g. Scoping Studies for reporting Mineral Resources at an early stage, Pre- and Feasibility Studies for reporting Ore Reserves.

\section{Conclusions}

During the last 2-3 years there has been an increased interest, both internationally and domestically, for investments in Greek resources. Exploitation opportunities for oil, gas, coal, metals and industrial minerals are in the news daily with comments and estimates from a variety of parties, including Industry Professionals, Academics and Journalists.

Although, it is difficult to regulate the partial information that the Journalists usually communicate in various media, it is important to regulate the information that the Companies, Professional Organizations and Individuals are releasing in order to have an adequately informed investment Community, as well as Public Opinion and Authorities. This regulated framework will allow for reasonable assumptions and cost-effective decisions to be made.

Academics and Industry Professionals, along with the respective Chambers in Geology and Mining Engineering disciplines, should work together towards establishing or adopting best industry practice tools and legislations, like PERC/JORC, which will promote the professional engagement, as well as add value to the domestic resource industry.

$\underline{\text { XLVII, No } 3-1633}$ 


\section{Acknowledgments}

Mark Berry from AMC Consultants, Brisbane, is acknowledged for valuable discussions on the revision of the JORC Code. I would also like to thank Peter Stoker from AMC Consultants, Brisbane, Australia, Professor Kimon Christanis from Department of Geology, University of Patras, Greece, and Adam Steward from Integral Resource Consulting Pty Ltd, Brisbane, Australia, for their critical recommendations, during the preparation of this manuscript.

(C) Joint Ore Reserves Committee 2012 An appropriate citation is: JORC, 2012. Australasian Code for Reporting of Exploration Results, Mineral Resources and Ore Reserves (The JORC Code) [online]. Available from: <http://www.jorc.org> (The Joint Ore Reserves Committee of The Australasian Institute of Mining and Metallurgy, Australian Institute of Geoscientists and Minerals Council of Australia). The Joint Ore Reserves Committee authorises the use and reproduction of this Code in part or in its entirety on the condition that the source is appropriately acknowledged. For further information please contact The AusIMM Publications Department on +6139658 6100 or via email: publications@ausimm.com.au.

\section{References}

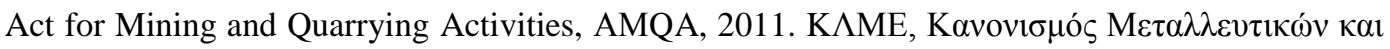
$\Lambda \alpha \tau o \mu \iota \kappa \omega ́ v ~ E \rho \gamma \alpha \sigma \iota \omega ́ v), ~ Ф E K ~ 1227-14 / 06 / 2011$, Available online at: www.sme.gr (in greek).

Australian Guidelines for Estimating and Reporting of Inventory Coal, Coal Resources and Coal Reserves, 2003. Coalfields Geology Council of New South Wales and the Queensland Mining Council, 8pp. Available online at: www.resources.nsw.gov.au.

Australian Securities Exchange (ASX), 2013. ASX Listing Rules, Chapter 5: Additional reporting on mining and exploration activities. Available online at: http://www.asxgroup.com.au/media/PDFs/Chapter05.pdf, 6pp.

Canadian Institute of Mining Metallurgy and Petroleum (CIM), 2011. CIM Standing Committee of Reserves Definitions, available online at: http://web.cim.org/standards.

Committee for Mineral Reserves International Reporting Standards (CRIRSCO), 2013. CRIRSCO International reporting template for exploration results, mineral resources and mineral reserves. Available online at: http://www.crirsco.com/template.asp.

Goddard I. 2013. The JORC Code's international reach and cooperation on Resource and Reserve Reporting through CRIRSCO, The AusIMM Bulletin, 3, 36-37.

Hunt S. 2013. Changed compliance requirements in the 2012 JORC Code. Available online at: http://www.asxgroup.com.au/media/PDFs/01-asx-resources-reporting-jorc-presentation.pdf.

Joint Ore Reserves Committee Code (JORC), 2012. Australasian Code for reporting of Exploration Results, Mineral Resources and Ore Reserves. Available online at: http://www.jorc.org, (The Joint Ore Reserves Committee of The Australasian Institute of Mining and Metallurgy, Australian Institute of Geoscientists and Minerals Council of Australia).

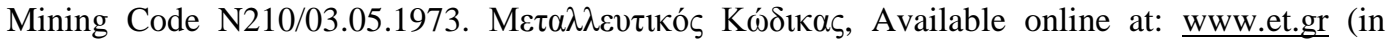
greek).

National Instrument 43-101, 2011. Standards of disclosure for mineral projects. Available online at: http://web.cim.org/standards/documents/Block484_Doc111.pdf, 44pp.

Pan-European Reserves \& Resources Reporting Committee (PERC), 2013. Pan-European standard for reporting of exploration results, mineral resources and reserves. Available online at: http://www.vmine.net/perc., 61pp.

Simon J. 2003. Three Australian asset-price bubbles. Available online at: http://www.rba.gov.au/publications/confs/2003/simon.pdf.

Stoker P. and Berry M. 2013. The JORC Code - Understanding and complying with the CODE. AMC Consultants Pty Ltd, Brisbane, Australia, 82pp.

UNFC 2009. United Nations Framework Classification for Fossil Energy and Mineral Reserves and Resources 2009, ECE Energy Series, vol. 39, 20 pp.

XLVII. No 3 - 1634 